\title{
HUBUNGAN DESMINOREA DENGAN AKTIVITAS BELAJAR PADA REMAJA PUTRI DI SMK NEGERI 1 TABANAN TAHUN 2020
}

\author{
Desak Made Firsia Sastra Putri, ${ }^{1,2}$ Putri Purnayanti ${ }^{1,2}$ \\ ${ }^{1}$ Prodi S1 Keperawatan Ners, ${ }^{2}$ STIKES Advaita Medika Tabanan \\ Korespodensi penulis:firshasastra86@gmail.com
}

\begin{abstract}
Abstrak
Latar belakang: Remaja atau masa pubertas merupakan masa peralihan dari anak-anak ke masa dewasa. Remaja merupakan mereka yang berada di rentan usia 10-19 tahun. Pada tahap ini remaja pasti akan mengalami suatu keadaan yang dinamakan menstruasi. Banyak gangguan menstruasi yang biasanya menyebabkan ketidaknyamanan fisik bagi seorang perempuan yang dapat mengganggu aktivitas mereka. Salah satu gangguan menstruasi ini biasanya menyebabkan ketidaknyamanan fisik yaitu dismenorea. Dismenorea merupakan kondisi dimana rasa yang sangat sakit di bagian perut dari mulai perut bagian bawah yang terkadang sakitnya bisa meluas sampai ke bagian pinggang, punggung bawah dan paha

Tujuan: Mengetahui hubungan antara disminorea dengan aktivitas belajar pada remaja putri di SMK Negeri 1 Tabanan tahun 2020.

Metode: Menggunakan teknik total sampling, jumlah responden sebanyak 37 orang remaja putri. Uji hipotesis dalam penelitian ini menggunakan Spearman Rank. Hasil penelitian menunjukan 17 responden $(45,9 \%)$ mengalami disminorea sedang dan sebanyak 18 responden $(48,6 \%)$ mengalami aktivitas belajar cukup. Didapatkan nilai $\mathrm{p}$ value sebesar $=0,003$ dngan nilai koefisien sebesar 0,9 yang artinya ada hubungan yang signifikan antara disminorea dengan aktivitas belajar pada remaja putri.

Simpulan : Ada hubungan antara disminorea denga aktivitas belajar pada remaja putri, dengan nilai koefisien sebesar 0,9 yang artinya terdapat kekuatan hubungan yang kuat dan menunjukan hubungan yang positif.
\end{abstract}

Kata Kunci: Aktivitas belajar, Disminorea, Remaja

\section{Pendahuluan}

Masa remaja merupakan salah satu tahap dalam kehidupan manusia yang sering disebut sebagai masa pubertas yaitu masa peralihan dari anak-anak ke masa dewasa. Menurut World Health Organization (WHO), remaja merupakan mereka yang berada di rentan usia 10-19 tahun. Menurut MenKes tahun 2013 total penduduk $28 \%$ atau 64 juta jiwa ialah usia remaja. Usia remaja merupakan suatu periode transisi dalam upaya menemukan jati diri dan kedewasaan biologis serta psikologi. Menurut hasil Survey Demografi dan Kesehatan Indonesia (SDKI) tahun 2012 jumlah penduduk dengan usia 10- 19 tahun mencapai 48 per 1000 perempuan (Departemen Kesehatan RI 2013).

Pada tahap ini remaja akan mengalami suatu perubahan fisik, emosional dan sosial sebagai ciri dalam masa pubertas (Panuju dan Umami, 2010). Remaja pasti akan mengalami suatu keadaan yang dinamakan menstruasi. Menstruasi atau datang bulan merupakan salah satu ciri dari perempuan yang sudah mengalami transisi dari kanakkanak ke dewasa dengan ditandai dari menarch (menstruasi pertama) sampai dengan menopause (berakhirnya masa menstruasi) (Pieter et al. 2011 dalam Yuniyanti et al. 2014). Menstruasi adalah perdarahan secara periodik dan siklus dari 
uterus, disertai pelepasan (deskuamasi) endometrium. Banyak gangguan menstruasi yang biasanya menyebabkan ketidaknyamanan fisik bagi seorang perempuan yang dapat mengganggu aktivitas mereka. Salah satu gangguan menstruasi ini biasanya menyebabkan ketidaknyamanan fisik yaitu dismenorea (Proverawati, 2014).

Berbagai macam faktor telah dicoba diidentifikasi untuk mengetahui faktorfaktor risiko yang terkait dengan kejadian dismenorea. Adapun yang termasuk di dalamnya ialah usia. Puncak kejadian dismenorea berada pada rentang usia remaja menuju dewasa yaitu 15 hingga 25 tahun dan akan menurun setelah melewati rentang usia tersebut. Selain usia, faktor risiko lain yang sering di teliti terkait dengan kejadian dismenorea ialah aktivitas belajar siswa. Remaja putri mengalami aktivitas belajar cukup dikarenakan belum sepenuhnya mengetahui dampak dari dismenorea yang menimbulkan kekhawatiran berlebihan sehingga tidak fokus saat mendengarkan penjelasan guru saat jam pelajaran. Akibat nyeri yang berkelanjutan menyebabkan remaja putri untuk tidak masuk sekolah. Faktor yang menyebabkan remaja putri mengalami aktivitas belajar cukup dikarenakan saat menstruasi remaja putri mengalami nyeri berat yang berdampak terhadap ketidaknyamanan mengikuti dan mendengarkan penjelasan dari guru. Berdasarkan data sebanyak $10 \%$ remaja putri mengalami aktivitas belajar kurang, hal ini perlu ditingkatkan dengan cara mengurangi rasa nyeri haid dengan mengkonsumsi obat penurun rasa nyeri haid dan mengurangi rasa cemas yang berlebihan saat haid karena sebagai gejala normal untuk meningkatkan kesuburan remaja putri. Cara lain yang perlu dilakukan guru saat memberikan pelajaran sehingga tidak menimbulkan rasa bosan pada siswa dengan menciptakan proses belajar yang nyaman dan tidak membosankan salah satunya adalah dengan lebih banyak melakukan interaksi dan tanya jawab. Saat ini Remaja putri mengalami aktivitas belajar yang cukup dikarenakan disminorea yang dialaminya. Hal ini dibuktikan dari hasil studi pendahuluan yang telah dilakukan oleh peneliti di SMK N 1 Tabanan pada tanggal 18 Oktober 2019. Dari 10 siswi yang diwawancarai hanya dua orang siswi yang mengungkapkan ketika mengalami disminore dapat mengikuti proses belajar dengan baik sedangkan delapan siswi lainnya mengalami kesulitan untuk berkonsentrasi selama jam pelajaran, mudahmerasa lelah dan malas sepanjang hari.Bahkan banyak siswi yang absensi selama dua sampai tiga hari dengan alasan kram di perut bagian bawah, merasa tidak enak badan, pusing dan takut tembus.

\section{Metode Penelitian}

Penelitian ini menggunakan metode analitik kuantitatif dengan menggunakan pendekatan cross sectional. Populasi dalam penelitian ini berjumlah 37 siswa jurusan teknik komputer jaringan(TKJ) yang terdiri dari siswa putri kelas $\mathrm{X}$ berjumlah 18 orang dan siswa putri kelas XI berjumlah 19 orang di SMK Negeri 1 Tabanan tahun 2020. Sampel dalam penelitian ini yaitu sebanyak 37 siswa putri kelas X dan XI jurusan teknik komputer jaringan (TKJ) yang diambil secara total sampling.Penelitian akan dilakukan selama satu hari pada bulan juni 2020 yang bertempat di SMK Negeri 1 Tabanan. Pengumpulan data dilakukan dengan cara memberi seperangkat pertanyaan atas pernyataan tertulis kepada responden untuk dijawabnya (Sugiono,2017). Dalam penelitian ini ada dua variabel yang akan diteliti yaitu hubungan disminorea dengan aktivitas belajar. Data diolah dengan analisis kuantitatif dimana dalam penelitian ini adalah analisa univariat dan bivariat. Analisa dilakukan dengan bantuan software komputer SPSS. 
3. Hasil dan Pembahasan

Tabel 1 Distribusi responden berdasarkan umur di SMK Negeri 1 tabanan

\begin{tabular}{lcc}
\hline \multicolumn{1}{c}{ Umur } & Frekuensi (f) & Persentase (\%) \\
\hline 16 tahun & 13 & 35,1 \\
17 tahun & 5 & 13,5 \\
18 tahun & 19 & 51,4 \\
\hline Total & $\mathbf{3 7}$ & $\mathbf{1 0 0}$ \\
\hline
\end{tabular}

Tabel 2 Distribusi frekuensi disminorea pada remaja putri di SMK Negeri 1 Tabanan

\begin{tabular}{lcc}
\hline \multicolumn{1}{c}{ Dismenorea } & Frekuensi (f) & Persentase (\%) \\
\hline Ringan & 11 & 29,7 \\
Sedang & 17 & 45,9 \\
Berat & 9 & 24,3 \\
\hline Total & $\mathbf{3 7}$ & $\mathbf{1 0 0}$ \\
\hline
\end{tabular}

Tabel 3 Distribusi frekuensi aktivitas belajar pada remaja putri di SMK Negeri 1 Tabanan

\begin{tabular}{lcc}
\hline \multicolumn{1}{c}{ Aktivitas Belajar } & Frekuensi (f) & Persentase (\%) \\
\hline Kurang & 9 & 24,3 \\
Cukup & 18 & 48,6 \\
Baik & 19 & 27,0 \\
\hline Total & $\mathbf{3 7}$ & $\mathbf{1 0 0}$ \\
\hline
\end{tabular}

Tabel 4 Hubungan antara disminorea dengan aktivitas belajar pada remaja putri di SMK Negeri 1 Tabanan

\begin{tabular}{lcccccc}
\hline \multicolumn{5}{c}{ Disminore } & \multicolumn{5}{c}{ Aktivitas Belajar } & p-value & $r$ \\
\hline & $\begin{array}{c}\text { Kurang } \\
\mathrm{f}(\%)\end{array}$ & $\begin{array}{c}\text { Cukup } \\
\mathrm{f}(\%)\end{array}$ & $\begin{array}{c}\text { Baik } \\
\mathrm{f}(\%)\end{array}$ & Total & \\
$\begin{array}{l}\text { Ringan } \\
\text { f }(\%)\end{array}$ & $3(27,3 \%)$ & $5(45,5 \%)$ & $3(27,3 \%)$ & $11(29,7)$ & 0.003 & 0,9 \\
$\begin{array}{l}\text { Sedang } \\
\text { f }(\%)\end{array}$ & $4(23,5 \%)$ & $8(47,1 \%)$ & $5(29,4)$ & $17(45,9)$ & \\
$\begin{array}{l}\text { Berat } \\
\text { f }(\%)\end{array}$ & $2(22,2 \%)$ & $5(55,6 \%)$ & $2(22,2 \%)$ & $9(24,3)$ & \\
\hline Total & $9(24,3 \%)$ & $18(48.6)$ & $10(27,0)$ & $37(100 \%)$ & \\
\hline
\end{tabular}

Berdasarkan tabel di atas, dari 37 responden diketahui umur remaja terbanyak yang ada di SMK Negeri 1 Tabanan yaitu usia 18 tahun yang berjumlah 19 responden $(51,4 \%)$. Berdasarkan tabel 2, dari 37 responden persentase tertinggi yang dialami remaja putri saat disminorea yaitu disminorea sedang dengan jumlah 17 responden $(45,9 \%)$. Hasil penelitian ini sejalan dengan penelitian yang dilakukan oleh Dwi Pranya Iswari et al (2014) yang menyatakan bahwa tidak satupun responden yang tidak mengalami disminorea. Hasil penelitian ini menunjukan bahwa karakteristik gejala dismenorea berdasarkan derajat nyerinya yang paling banyak dialami responden adalah dismenorea sedang sebanyak 140 siswa $(88,6 \%)$ sedangkan dismenore berat yaitu 18 siswa $(11,4 \%)$. Penelitian yang serupa juga dilakukan oleh (Amaliya Alimudin, 2017) yang menyatakan bahwa mayoritas siswa yang mengalami dismenorea sedang mengakibatkan aktivitas belajarnya terganggu. Responden yang mengalami disminorea sedang sebanyak 37 $(48.4 \%)$, responden yang mengalami disminorea ringan sebanyak $6(9,4 \%)$ dan responden yang mengalami disminorea berat sebanyak $21(32,8 \%)$.

Berdasarkan tabel di atas dijelaskan bahwa dari 37 responden sebagian besar aktivitas belajarnya cukup dengan jumlah 18 
responden $(48,6 \%)$. Hasil penelitian ini sejalan dengan penelitian yang dilakukan oleh (Amaliya Alimudin, 2015) yang menyatakan bahwa aktivitas belajar cukup sebanyak 72 (66\%), aktivitas belajar kurang sebanyak $29(27 \%)$, dan aktivitas belajar baik sebanyak 8 (7\%). Banyak remaja putri yang mengalami gangguan dalam aktivitas belajar yang diakibatkan karena disminorea (nyeri haid) yang dirasakan dalam proses belajar mengajar yang menyebabkan remaja putri sulit untuk berkonsentrasi karena ketidaknyamanan yang dirasakan ketika mengalami disminorea. Hal tersebut membuat sebagian prestasinya kurang baik karena sering tidak mengikuti pembelajaran di sekolah.

Berdasarkan tabel 4 di atas menggambarkan bahwa remaja putri yang mengalami disminorea ringan sebanyak 11 responden $(30 \%)$ dengan aktivitas belajar kurang sebanyak tiga responden $(27,3 \%)$, aktivitas belajar cukup sebanyak lima responden (45,5\%) dan aktivitas belajar baik sebanyak tiga responden (27,3\%). Remaja putri yang mengalami disminorea sedang sebanyak 17 responden (46\%) dengan aktivitas belajar kurang sebanyak empat responden $(23,5 \%)$, aktivitas belajar cukup sebanyak delapan responden $(47,1 \%)$ dan aktivitas belajar baik sebanyak lima responden (29,4\%). Remaja putri yang mengalami disminorea berat sebanyak sembilan responden (24\%) dengan aktivitas belajar kurang sebanyak dua responden $(22,2 \%)$, aktivitas belajar cukup sebanyak lima responden $(55,6 \%)$ dan aktivitas belajar baik sebanyak dua responden $(22,2 \%)$.

Berdasarkan uji statistik spearman rank yang digunakan dalam menganalisis kedua variabel, didapatkan hasil nilai $\mathrm{p}$ adalah 0,003 yang memiliki nilai kurang dari 0,05 yang berarti Ha diterima yaitu ada hubungan antara disminorea dengan aktivitas belajar pada remaja putri di SMK Negeri 1 Tabanan. Kekuatan hubungan antara disminorea dengan aktivitas belajar yaitu 0,9 yang artinya terdapat hubungan yang kuat dan menunjukan hubungan yang positif. Penelitian ini sejalan dengan penelitian sebelumnya yang dilakukan oleh (Amaliya Alimudin, 2015) yangmenunjukan bahwa ada hubungan antara dismenorea dengan aktivitas belajar pada remaja putrid dengan nilai $p<0,05(p=0,00)$ artinya Ho ditolak dan Ha diterima sehingga hasil penelitian ini menunjukan bahwa remaja putri yang mengalami dismenorea sedang dan berat merasa bahwa aktivitas belajarnya terganggu dan berpengaruh terhadap prestasi di sekolah.Penelitian ini juga sejalan dengan penelitian yang dilakukan oleh (Fersta, 2014) yang menunjukan bahwa terdapat hubungan yang bermakna antara dismenore dengan aktivitas belajar $\mathrm{p}<0,01$ penelitian ini menunjukan jika seorang remaja putri yang mengalami dismenorea maka aktivitas belajar mereka di sekolah terganggu karena tidak dapat berkonsentrasi belajar pada saat proses belajar mengajar dan motivasi belajar akan menurun dan tidak jarang hal ini membuat mereka jarang masuk kesekolah serta kualitas hidup menurun.

\section{Simpulan}

Berdasarkan hasil penelitian yang dilakukan peneliti dapat disimpulkan bahwab Terdapat hubungan antara disminorea dengan aktivitas Belajar di SMK N 1 Tabanan.

\section{Referensi}

Alimuddin, A.(2017). Hubungan Disminorea Dengan Aktivitas Belajar Mahasisiwa Prodi DIV Jurusan Kebidanan. Kendari: Amaliya Alimuddin

Astrida, Rakhma. (2012) Gambaran Derajat Dismenore Dan Upaya Penanganannya Pada Siswi Menengah Sekolah Kejuruan Arjuna Depok Jawa Barat.Thesis Jakarta UIN Syarif Hidayatullah.

Atikah Proverawati dan Siti Misaroh.(2012). Menarche Menstruasi Pertama Penuh Makna. Yogyakarta: Nuha Medika.

Iswari. P D, Surinati, \& Mastini, (2014). Hubungan Disminorea dengan Aktivitas Belajar Mahasiswi PSIK FK UNUD 
Nursalam. (2010). Konsep dan Penerapan Metodologi Penelitian Ilmu Keperawatan Pedoman Skripsi Tesis dan Instrument Penelitian. Jakarta: Salemba Medika

Proverawati dan Misaroh. (2009). Menarche Menstruasi Pertama Penuh Makna.Yogyakarta: Nuha Medika

Pakaya, Desriani (2014). Hubungan Faktor Resiko dengan Kejadian Dismenorea Primer pada Siswi Kelas VIII SMPN 6 Gorontalo Tahun 2013. Gorontalo: Universitas Negeri Gorontalo

Panuju, Panut dan Ida Umami. (2010) Psikologi Remaja, Yogyakarta: Tiara Wacana Yogya.

Sugiyono. (2017). Metode Penelitian Kuantitatif, Kualiatif, Dan R\&D. Bandung: Alfabeta 